\title{
CONTINENTVR HOC OPERE
}

Conspectus editionum librorumque $\ldots \ldots \ldots \ldots$

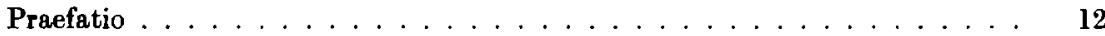

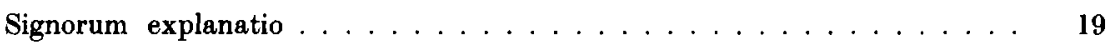

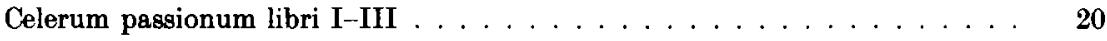

Tardarum passionum libri I-II . . . . . . . . . . . . . 426

Tardarum passionum libri III-V . . . . . . . . . . . 678

Corrigenda . . . . . . . . . . . . . . . . . . 949

Indices . . . . . . . . . . . . . . . . . . . 949

I. Index nominum . . . . . . . . . . . . . . . 943

II. Index uerborum $\ldots \ldots \ldots \ldots \ldots \ldots \ldots \ldots \ldots$

III. Voces Graecae Graecis litteris scriptae . . . . . . . . . . . . . . . 1219

IV. Voces Graecae Latinis litteris scriptae . . . . . . . . . . . . . . . . 1220 



\section{CAELII AVRELIANI}

TARDARVM PASSIONVM

LIBRI III-V

CAELIUS AURELIANUS

CHRONISCHE KRANKHEITEN

BUCH III-V 
